\title{
ThE FURTHER ADVENTURES AND STRANGE AFTERLIFE OF THE OIL AND GAS LEASE
}

\author{
JOIN BISIIOP BALLEM, Q.C.
}

\section{INTRODUCTION}

Two cases involving the oil and gas lease recently arrived at the end of the litigation trail when the Supreme Court of Canada dismissed applications for leave to appeal in Freyberg v. Fletcher Challenge Oil \& Gas Inc.' and Montreal Trust Co. v. Williston Wildcatters Corp.' Although both cases are important and deal with significant legal principles, it is not surprising that they failed to make it onto the crowded docket of the Supreme Court. The rate of success of applications for leave to appeal in civil cases hovers around 10 percent or less. ${ }^{3}$

\section{FREYBERG}

In Freyberg, the Alberta Court of Appeal was required to revisit and reaffirm some familiar and well established principles after the trial court ventured into unexpected territory. The parties agreed that during the first stage of the trial, the Court would only deal with the alleged termination of the lease, and not with the consequences if the lease was found to have terminated. At the time of writing, the lease had been held to have terminated, but the second stage has yet to be heard.

\section{A. FACTS}

The plaintiff was the lessor under a natural gas lease dated 13 November 1975. In October 1978, during the five year primary term of the lease, a natural gas well was drilled on the lands. $A$ drill stem test was carried out, indicating a flow of gas at 6.065 million cubic feet per day. Despite this encouraging result, no operations by way of completing, testing, or placing the well on production were conducted during the period from rig release in 1978 to the completion and testing of the well in December 1998. Shut-in royalty payments from the time the well was shut-in to the time the well was placed on production were made by the lessee. The shut-in payments were found to have been properly made.

Counsel, Gowling Lafleur Henderson. Calgary, Alberta.

2002 ABQB 692, 323 A.R. 45, rev'd 2005 ABCA 46, 363 A.R. 35, leave lo appeal to S.C.C. refused. [2005] S.C.C.A. No. 167 [Frobergl.

: L.ease validily trial: 2001 SKQB 360, [2001] S.J. No. 636(QL), afrd 2002 SKC A 91, 233 Sask. R. 276, leave to appeal w S.C.C. refused, [2002] S.C.C.A. No. 392 [H'illisfon 2002]. Remedies: 2003 SKQB 360, 239 Sask. R. 57, revid 2004 SKC A I 16, 254 Sask. R. 38, leave lo appeal to S.C.C. refused. [2004] S.C.C.A. No. 474 [Willision 2004].

3 Brian A. Crane \& Henry S. Brown, Supreme Court of Canadu Practice 2005 (Toronto: Thomson Carswell, 2004) at $18-30$. 


\section{B. IsSUES}

The significant issues that the trial and appeal courts had to address were:

- Can the default clause apply to preserve the lease and limit the lessor's remedy to one for damages when there is no production, deemed or actual, in the secondary term?

- Which pary has the onus in determining whether or not there was an economic and profitable market?

- What is the test to be applied in making this determination?

- On a narrower but relevant issue, both the trial and appeal courts held that a postdated cheque, timely mailed and negotiable on the due date, constitutes proper payment of a shut-in royalty.

In upholding the lease, the trial judge relied on two alternative grounds: that there was a lack of an economic or profitable market, or that in any event, the default clause would operate to prevent the lease from being terminated.

\section{The Market Test}

Clause 3 of the lease provided as follows:

\section{Shut-In Gas Wells:-}

If at the expiration of any year during the primary term or any extended term of this Lease there is no producing on the said lands or pooled lands but there is a well on the said lands or the pooled lands which is designated a gas well by or pursuant to any applicable statute or regulation, or by the board, governmental authority or agency having jurisdiction in that regard, and from which no leased substances are being produced as a result of the lack of an cconomical or profitable market. such well shall be deemed to be a producing well on the said lands under all the provisions of this Lease and the Lessee shall, on or before such anniversary date, pay to the Lessor in the same manner provided for the payment of the delay rental liercunder, as royalty, an amount equivalent to the delay rental. Like payments shall be made in a like manner on each successive anniversary date during the period that such well is deemed by vinue of this Clause to be al producing well on the said lands. ${ }^{+}$

Since there was no production during the lengthy period between 1978 and 1998, and the primary term having long since expired, the lessee sought to maintain the lease in force by shut-in payments pursuant to cl. 3. This clause provides that if no leased substances are being produced "as a result of the lack of an economical or profitable market, such well shall be deemed to be a producing well." Therefore, if the well is deemed to be producing, the lease will continue in force past the primary term under the habendum clause so long as shut-in payments are made. 
The lack of an economical or profitable market is the sine qua non of the lessee's right to make shut-in payments and preserve the lease. The question of when and how such a lack occurs is of prime importance to the oil industry. Many wells, particularly natural gas wells, have been shut-in for protracted periods, Freyberg being in the extreme range in this regard. In recent years the price of natural gas has risen dramatically and many of these long shut-in wells have been placed on production.

It is fair to say that there were compelling facts in Freyberg to contradict the lack of an appropriate market. The drill stem test conducted at the time the well was drilled indicated a very favourable flow rate of 6.065 million cubic feet per day. Other wells in the vicinity were placed on production during the 1980s. The importance of the case, however, lies not in its particular fact pattern, but for the general principles and judicial guidelines that may be derived from it.

\section{ONUS}

The starting point for the determination of the existence of a market is the question of who has the onus? The lessee or the lessor?

The trial judge held that there was no reason to shift the onus from the lessor who asserts that there was an economic or profitable market, to the lessee. This ruling was based on the fact that both parties were equally able to present expert evidence at trial.

On appeal, this approach was criticized as treating the question of an economical or profitable market as "merely a contest of experts." The Court of $\wedge$ ppeal went on to place the onus on the lessee to establish the negative market conditions that would justify the making of shut-in payments under the lease. The overall onus of proving the case remains with the plaintiff, but on the matter of deemed production, the onus is on the lessee due to: (a) the lessee's reliance on an exception (cl. 3) to the lease's termination; and (b) the lessee's specialized knowledge and awareness of relevant facts not available to the lessor.

The Court of Appeal overturned the trial judge's decision that there was no economical and profitable market. The trial judge found that there had not been an economic and profitable market in holding that the decision of an honest lessee who has considered all of the material factors will not be second guessed by the courts. The Appeal Court found this approach to be "overly subjective" and held that well economics can only be analyzed prospectively. The test is whether, based on information available at the time, a prudent lessee would have foreseen profitability.

\section{E. The Alternate Ground}

Since the lessee had lailed the market test, the scope and effect of $\mathrm{cl} .18$ of the lease also had to be reviewed on appeal. 


\section{F. What Constitutes a Default?}

The most disconcerting aspect of the trial judge's decision was the finding that the default clause operaled to prevent termination of the lease and to limit the lessor's remedy to damages. Clause 18 of the lease provides as follows:

\section{Default:-}

In the case of the breach or non-observance or non-performance on the pan of the Lessec of any covenant, proviso, condition, restriction or stipulation herein contained which has not been waived by the Lessor, the Lessor shall, before bringing any aclion with respect thereto or declaring any forfeiture, give to the Lessec written notice stiting forth the particulars of and requiring it to remedy such default, and in the event that the Lessec shall fail to commence to remedy such default within a period of Ninety (90) days following receipt of such notice, and therealter diligently proceed to remedy the same, then except as hereinafler provided. llis Leuse shall thereupon terminate and it shall be lawful lior the Lessor into or upon the said lands (or any part thereof in the name of the whole (o) re-enter and the same to have again, repossess and cnjoy [sic]; IPROVIDLED that this Lecase shall not terminate nor be subject to forfeiture or cancellation il there is located on the said lands or the pooled lands a well capable of producing the leased substances or any of them, and in the event the Lessor's remedy for any delault hereunder shall be in damages only. ${ }^{5}$

The probiem with cl. 18 is that it applies only to covenants, provisos, conditions, restrictions, or stipulations, all of which envisage some form of obligation or duty. In order to come within its ambit and protection, the lessee must have breached some obligation. While the shut-in well clause provides that "the Lessee shall pay," the courts have ruled the clause grants the lessee an option, not an obligation, to make the payment. ${ }^{6}$ Thus, in order to make the default clause applicable, the trial judge was forced to imply a term in the lease that the lessec must produce gas from the lands in the secondary term. This necessitated treating the secondary term as imposing stricter obligations on the lessee than in the primary term. With respect, this represents a considerable stretch on the part of the Court. Having somehow implied such a term requiring the lessee to produce in the secondary term, the tria] judge was able to bring the failure to produce within $\mathrm{cl}$. 18, and thus hold that the lessor's remedy was limited to damages and not termination of the lease.

The Court of Appeal made short work of this approach, finding that there was no such implied term, and that the lessee's decision to produce or not to produce was in the nature of an option and not an obligation. Therefore, the default clause had no application. This finding by the Court of Appeal is consistent with existing case law. ${ }^{7}$

Durish v: White Resource Management (1987), 82 A.K. 66 (Q.B.) at para. 3, afT (1988), 63 ᄉlta. L..R. (2d) 265 (C.A.).

Sec Easi Crest Oil Co. v. Strohschein and Strohschein. [1952] 2 D.L.R. 432 (Alta S.C. (A.D.)). See also Chipp v. Hum (1955), 16 W.W.R. 209 (Alta. S.C. (T.D.)). 


\section{G. ESTOPPEL}

Because of a comment by the trial judge that the lessees made out a strong case for estoppel, although the judge "cites no legal principles in support of estoppel," the Court of Appeal felt compelled to consider the matter "afresh." The Court found that before the lessor could be estopped by her acceptance of the shut-in payments, she must have known not only of her rights, but also of the underlying facts. Additionally, the lessees must have relied on her election to their detriment. The lessor's lack of knowledge was sufficient to negate any estoppel. The Court of Appeal also noted that the Supreme Court has expressed doubl as to whether estoppel could ever operate to revive a terminated lease."

\section{H. What FREYBERG TellS US}

In overturning the trial decision and striking down the lease, the Court of Appeal essentially reaffirmed existing principles and precedents:

- The default clause applies only to obligations on the part of the lessee.

- There is no implied obligation on the lessec to produce the leased substances in the secondary term.

- The onus of establishing the lack of an economical and profitable market lies with the lessee.

- The market test is whether, based on information available at the time, a prudent lessec would have foreseen profitability.

\section{WILLISTON}

Like Freyberg, the Williston case was heard in two stages, both of which have been heard and finally determined. The first stage dealt with the question of termination of the petroleum and natural gas lease, and the second dealt with the state of affairs once the lease was found to have been terminated.

\section{A. FACTS}

The mineral owners granted a petroleum and natural gas lease on 26 February 1952. The primary term was for ten years pursuant to the habendum which provided:

TO HAVE AND ENJOY the same for the term of Ten (10) years from the date hereof and so long thercafter as the leased substances or any of them are produced from the said lands, subject to the sooner termination of the said Ierm as hereinafter provided. 
AND FURTHER ALWAYS PROVIDED that if at any lime alter the expiration of the said Ten (10) year term the leased substances are not being produced on the said lands and the Lessee is then engaged in drilling or working operations thereon, this lease shall remain in force so long such operations are prosecuted and, if they result in the production of the leased substances or any of them, so long thereafler as the leased substances or any of them are produced from the said lands; provided that if drilling, working or production operations are interrupted or suspended as the result of any cause whatsoever beyond the Lessee's control, the time of such interruption or suspension shall not be counted against the Lessec, anything hercinbetore contained or implied to the contrary notwithstanding."

An oil well was drilled on the leased lands and, as of November 1955, was producing. As the years went on, production gradually decreased. There was some question as to whether there was production during a three month period in 1989, but as indicated later, this was resolved in favour of the lessee. During January 1990, the well was shut-in and there was no production from 2 January to the end of July 1990. During this seven month period the lessee carried out certain activities with respect to the lands. In July 1990, the lessee began servicing the well and production returned in August and continued until May 1991 when the well was permanently shut-in. A new well was drilled on the leased lands and completed on 28 May 1991. Production from this well commenced in the following month.

On 11 March 1992, the lessors wrote to the lessees raising the possibility that the lease had terminated sometime in the past. This was followed by a letter erroneously dated 1 April 1991. It was common ground that the correct year was 1992. This letter stated that the lessors

were "not yet requiring that the operator vacate the property." "(This letter is quoted in full in the discussion of leave and licence.) On 26 February 1993, an action was commenced by the lessors seeking a declaration that the lease had terminated.

\section{B. TrRMINATION}

The trial judge considered two periods of time: the three months from the beginning of January 1989 to the end of March 1989, and the first seven months of 1990. Each lease year would expire at midnight, 25 February.

The trial judge decided from the evidence that there had been actual production during the first period and, therefore, the lease was continued beyond that date.

\section{WORKING OPERATIONS}

It was clear from the evidence that there was no production during the second period, in 1990. There was no production after 2 January 1990 to the end of July. That being so, it then became necessary to determine whether or not the lease was extended by working or production operations as provided in the habendtum.

The well was back on production in August 1990 and the Court accepted the service work performed in July as meeting the requirements of the lease. However, the Court held that it

"Williston 2004 (C.A.), supra note 2 at para. 20 [cmphasis omitted]. 
was the activity prior to July that had to be looked at. The lessee was able to point to a number of events as follows:

- In the winter of 1989-90, snow was ploughed to facilitate access to the well site.

- The lessee had purchased a service rig which had to be removed from its existing site and be refurbished, which continued throughout the first half of 1990 . It did not perform any work on the well during this period.

- The field operator attended the well in March and thawed out the flow line and started the well, but the line froze. In May a fence was built around the well to keep out cattle and a dugout was built for the surface owner to replace his dugout that had been contaminated by salt water discarded from the well.

- During 1990, the lessec paid the surface lease rent and taxes and filed reports with the Saskatchewan government, paid the mineral tax, and corresponded with the plaintiff.

The trial judge then considered whether such operations amounted to "working operations."12 After noting that there had been no decisions on the point, he ruled that "working operations" must be activities that are directed to bring about the production of oil, and that the activities of the lessee in 1990 did not fit within the description. In so finding, he dismissed the efforts to thaw the flow line in January and March as isolated acts and not meaningful attempts to restore production.

Nor could the lessee rely upon the proviso in the habendum that if working operations are interrupted or suspended as the result of any cause beyond the lessee's control, the time of such interruption of suspension shall not be counted against the lessee. The lessee submitted that the winter weather and the imposition of road bans were causes beyond its control. The trial judge dismissed the winter weather conditions as an ongoing situation that the oil industry had learned to deal with. Similarly, road bans were dismissed as not being beyond the lessee's control. In this, the Court followed Canada-Cities Service Perroleum Corp. v. Kininmonth. ${ }^{13}$

The trial judge's decision that the lease had terminated was upheld by the Court of Appeal, ${ }^{14}$ which essentially adopted the reasons of the court below. The finding is consistent with existing case law. 's The most noteworthy aspect is the declaration that the work performed must be directed to production. At the end of the first trial on 2 November 2001 the parties entered into a consent order permitting the lessee to continue producing the well with the proceeds being paid into court. 


\section{REMEDIES}

The lease having terminated, the trial proceeded to the second stage: to determine the appropriate remedies. It was conceded that operating the existing well and drilling a new well on the lands constituted a trespass.

The trial judge rejected the lessee's argument that the trespass was permitted by reason of leave and licence. Specifically, the trial judge found that it could not be said that the lessor was extending leave and licence to occupy the lands. Rather, it had communicated its position to the lessee and then let things be to await the outcome of the action. As the Court noted, such an approach was not uncommon, and the lessee thereafter proceeded at its own risk.

\section{E. RESTITUTION OR DAMAGes?}

Not surprisingly, the views of the plaintiff lessor and the defendant lessee as to the financial consequences of the lease's termination differed widely. The lessor submitted that they should be equal to the net revenue realized from the production of petroleum from the two wells. This approach would result in an award of some $\$ 1,500,000$, while the defendant argued that the lessor's compensation should be an increased gross overriding royalty. This would result in an award of some $\$ 183,000$.

The trial judge commenced his analysis by noting that the normal measure of damages is that which will restore the plaintiff to its original position prior to the commission of the wrongful conduct. He noted there were two rules to be considered in quantifying damages where valuable property, such as minerals or trees, have been removed from the land by way of trespass.

The first rulc, which is described as severe, holds that the plaintiff should receive the value of what was produced without any allowance for the cost of production. The judge cited two cases that held this rule applies where the trespass is wilful or fraudulent. ${ }^{16}$

The second, milder, rule holds that in calculating the value of the produced goods, an allowance should be made for the cost of production. It is similar to a calcgory of restitution where a party seeks to recover payment for services rendered or work performed. ${ }^{17}$ This rule, which was essentially what the plaintiff lessor had asked for, applies where the trespass

16 Ifartin : Porter (1839), 151 F..R. 149 (Fng. Ex. C1.) and Wasson v. California Stamdard Co. (1964), 47 D.L.R. (2d) 71 (Alta. S.C. (A.D).)).

1: G.H.L. Fridman, Restitution, $2 \mathrm{~d}$ ed. (Scarborough, Ont.: Carswell, 1992) at 24, 25. Professoor David Percy deals specifically with restitution and terminated leases in his article, "The Law of Restitution and the Unexpected Termination of Petroleum and Natural Gas Leases" (1988) 27 Alta. L. Rev. I05. In this article I suggest that the Saskatchewan courts, by applying the concept of "damages," have gone well beyond restitution. 
occurred because of inadvertence, mistake, or honest belief. The Court cited a number of coal and lumber cases where it had been followed. ${ }^{18}$

The trial judge then turned to an oil and gas case, Weyburn Security Co. v. Sohio Petroleum Co., 19 where the Supreme Court agreed with the Saskatchewan Court of Appeal in holding that the lessee, Sohio, first became aware that its position was challenged when the writ of summons was served on them. By that time the revenue that Sohio had received from the production exceeded the expenditures. Under these conditions, both courts agreed that it would appear "just and equitable" for the lessee to account for all benefits from production received by it after the date of service of the writ of summons.

I pause at this point to remark that I find the concept of "damages" to be troubling in the context of the oil industry, in that it does not reflect the realities of the situation between the two parties. Surely what is involved is the question of ownership of, and entitlement to, the substances once the lease has ceased to exist. It must also be noted that the focus has shifted from the lessee's right, if any, to be compensated for work done and services performed, to what damages the lessori should be awarded. This shift in judicial approach led to a very different result from that which would have been reached if the doctrine of restitution had been applied.

In Williston, however, the trial judge seized on the "just and equitable" aspect to arrive at a result that Professor Bankes, in his admirable article, ironically terms the "really mild rule." In reaching this "really mild" result, the trial judge noted that the lessor would not have developed the property itself, rather it would have relied on a third party - presumably an operating oil company - 10 do so. The evidence was that the lessor had al ways developed properties by way of granting leases. It should be remembered that Montreal Trust was a "nominal" plaintiff, holding the mineral rights in trust for the unit holders. The Court then looked at the position the mineral owner would be in if the lands were not occupied by the defendant. There was evidence that the plaintiff - Montreal Trust - could have obtained a royalty of 18 percent and a bonus of $\$ 6400$ for a lease at the time the subject lease terminated. The plaintifflon behalf of the group had already done so with respect to some nearby lands.

Abandoning both the "harsh" and "mild" rules, the Court used this evidence to "restore" the plaintiff to the same position it would have been in before the trespass, and awarded the plaintiff the sum of $\$ 6400$ by way of bonus, and increased the applicable royalty rate from the 12.5 percent specified in the lease, to 18 percent.

The Saskatchewan Court of Appeal in Williston also used the "really mild rule" in determining the lessor's remedy. Unlike the trial court, the Court of Appeal applied "leave

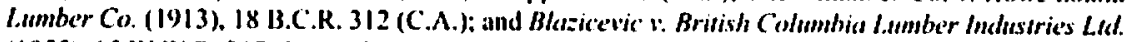
(1955), 15 W.W.R. 317 (B.C.S.C.).

19 [1971] S.C.R. 81 [ Weyburn].

30 Nigel Bankes, "Termination of an Oil and Gas L.easc, Covenants as to Title, and Assessment of Damages For Wrongful Severance of Natural Resources: A Comment on Willistom Wilteaters" (2005) 68 Sask.

L. Rev. 23. This article is a detailed and perceptive critique of the appropriate remedies. 
and licence," so that the period during which the damages were payable lasted only from January 1990 to March 1992 when leave and licence took effect. No damages were incurred after that date since the defendants paid the 12.5 percent royalty due under the lease for the relevant time period. In the result, the Court of Appeal endorsed and applied the "really mild approach," although not calling it that.

The problem with this approach to damages is that it inevitably reaches a different result depending on the circumstances of the lessor. If the lessor is an ordinary private citizen with no operating experience, the damages would be limited to whatever bonus and royalty rate the court believed he or she could negotiate at the time of the termination. On the other hand, if the lessor happened to be an oil industry entity, the appropriate damages would appear to be the revenues less the cost of production.

Not only does the "really mild rule" lead to different results depending on the circumstances of the lessor, it requires the court to speculate on what an individual lessor might or might not do. The fact that the mineral owner may not be presently involved in the oil industry does not preclude him or her from hiring independent contractors to operate the properties. It also requires the court to delve into the affairs of the plaintiff, a task for which it is ill-equipped. For example, the trial judge in Williston, Gerein J., referred to evidence from one of the plaintiff's managers that it had always developed properties by way of leases. The plaintiff itself was not a mineral owner, but a trust company. Presumably, what was meant was that the unit owners as a group had always followed this course with respect to their lands. The judge also referred to the evidence of one of the unit holders (who was an active participant in the oil industry) that he was not interested in undertaking the risk of drilling operations on the property because the economic prospects were not good. But this might not be the case with someone more optimistic about the prospects.

Even more disturbing is that this method of determining damages could encourage the lessee to continue producing the well after the lease has been challenged, knowing the financial consequences will not be severe. Indeed, it would be very much to the lessee's advantage to do so as the result could end up being almost the same as if the lease were valid. If the bonus consideration and the royalty rate happened to be the same as were commonly obtained at the time the lease terminated, it would appear that the mineral owner would not be entitled to any compensation whatsoever. This despite the fact that the lessee had enjoyed revenue from the production of minerals to which it had no legal title.

Aware that there might be concern over the potential of the "mild rule" to lead to abuse by a lessee, the Court of Appeal had this to say:

Arguments that suggest that this will encourage trespassers to be careless as to whether they act legally or not should be instantly quelled: a trespasser who does so is almost certain to fall under the harsher head of damage due to their negligence or bad faith, and thus this option of damages is not even open to the Court. ${ }^{21}$ 
This statement, meant to be reassuring, bears scrutiny. Consider: the vast majority of lessors will be private citizens, not oil industry players (more than 26,000 mineral owners in the Province of Alberta are individuals), and the elapsed time between the statement of claim and the final determination of the status of the lease can last for years. In Williston, the statement of claim was issued in 1993, but the final judicial decision that the lease had terminated in 1990 did not occur until 2002. In Anderson v. Amoco Canada Oil \& Gas, ${ }^{22}$ a case involving the ownership of solution gas that migrated into the gas cap as the reservoir pressure was reduced by production, the elapsed time was from 1992 to 2004.

The years between tho challenge and final resolution could well encompass the period of prime production from the lands. A lessee, knowing that the worst case scenario would require only an upward adjustment in the royalty rate and possibly some additional bonus, would naturally be tempted to remain in possession and appropriate the production revenues to itself. Even if it was aware of the likelihood that the lease was no longer valid, and even if it used all available stratagems to prolong the judicial process, it could scarcely be charged with acting in bad faith. It would only be exercising its legal rights.

All this leads me to suggest that Professor Bankes' ironic characterization of the result in Williston as the "really mild rule" might well be taken a step further, and what we have is the "too mild rule."

\section{F. FaCt SPECIFIC}

The facts in Williston were unique because of the way the plaintiff expressly encouraged the lessee to remain in possession and continue to produce the leased substances. In its letter of 1 April 1991, the plaintilf" wrote, "[t] he unitholders are certainly not yet requiring that the operator vacate the property. "23 Later in that same letter, the plaintiff mentioned that the unit holders had recently granted a lease at a rate of 18 percent "and this may be acceptable to them once again."

This non-aggressive approach undoubtedly influenced the courts in their assessment of damages. It also, it is submitted, severely limits the applicability of the decision as a precedent in future cases.

\section{G. Leave and Licence}

The rationale of the Williston case on the question of whether or not the lease had terminated both followed and applied long accepted legal concepts. ${ }^{2 s}$

In dealing with the question of what happens after a lease has been terminated, however, the Saskatchewan Court of Appeal turned to the doctrine of leave and licence. The doctrine is not entirely new to the law pertaining to oil and gas leases. As far back as 1935, the 
Alberta Appellate Division invoked leave and licence where the mineral owner, "with full knowledge of his position, deliberately refrained from interfering with the defendant's drilling operations in the hope that the fruits of the defendant's labour and expenditure would fall into his lap." ${ }^{26}$ In more recent times, beleaguered lessees have relied on estoppel in its various forms. In view of the singular lack of success of estoppel in preserving the lease, we may expect to see more of its close relative, leave and licence.

The following facts are relevant to leave and licence: on 11 March 1992 the lessor wrote to the then operator suggesting that the lease had terminated sometime in the past. This suggestion was not accepted by Williston. Shortly thereafter, on I April 1992, the plaintiff wrote as follows:

I apologize for the delay in responding to your phone call.

Since we spoke, I have received phone calls from a number of unitholders in our Trust. The consensus secins to be that they would request documentation supporting any AMidavit submitted by TDL, with regard to aclivity on these lands for the January 1990 to July 1990 period. This documentation could include invoices, ctc.

The unitholders are certainly not yet requiring that the operator vacate the propeny should the Affidavit not be forthcoming. They would, however, consider granting a new lease on the property. This group recently granted a lease at a rale of $18 \%$ and this may be acceptable to them once again. I would be glad to forward an offer to my clicnts should your clients wish to submit one.

As I mentioned in my carlier letter to Mary Tidlund, no approval of further work in this area will be given by the unitholders of this Trust until this matter has been resolved. ${ }^{2 ?}$

On 26 February 1993, the lessor commenced a court action for a declaration that the lease had terminated.

As previously indicated, this action determined that the lease had ceased to exist as of January 1990 , although the question was not finally resolved until 2002 when leave to appeal to the Supreme Court was refused.

The trial judge noted, and the parties agreed, that any operations on the lands, including the subsequent production of an existing well and the drilling of a new well, constituted a trespass. The question, however, was whether that trespass came to an end by reason of leave and licence. The trial judge held that the correspondence and the fact that royalties continued to be paid and accepted did not amount to leave and licence allowing the lessee to continue to occupy the lands.

The trial judge further held that for the period from 3 January 1990, when the lease terminated, to March 1992, none of the parties knew of the termination and, therefore. there could be no acquiescence. 
The next period from 11 March 1992 (being the date of the letter) to 26 February 1993 (when the action was commenced), was described as being only somewhat more problematic. The plaintiff did not ask that the lands be vacated, and in its follow-up letter of April 1992, it expressly stated that it was not asking the lessee to move off the lands. The lessor also continued to receive royalty. The trial court held that the conduct must be looked at in context. During that period, the lessor could not be certain that the lease had terminated. The whole tenor of the relationship was one of disagreement, thus the Court could not accept that the lessor was granting authority to occupy the lands. The lessees were proceeding at their own risk.

The Court of Appeal overturned the trial judge's finding that the lessor had not granted leave and licence. On the subject of damages during the short period, during which it held a trespass had occurred - January 1990 to 11 March 1992, the latter date being the date of the letter from the lessor that, in the view of the court, created the leave and licence - the Court of Appeal agreed with the trial judge that the damages should be based on the best royalty available at the time plus a bonus.

The Court of Appeal found that the lessec's trespass had ended by reason of leave and licence, which it inferred from the correspondence and actions of the lessor. In effect, this permits the lessee to continue to occupy the lands and receive the revenues to the same extent as if the lease were still lin force.

In the context, and in light of $W e y b u m,{ }^{28}$ it is difficult to see how the lessee could fail to be aware that its title was being challenged when the writ of summons was issued.

If nothing else, the Court of Appeal decision points out the hazards that await a lessor in the period between the time the lease is challenged and the final judicial determination on the point. If the lessor accepts royalties, does that amount to leave and licence? Probably not, but correspondence suggesting that the lessee could remain on the land and continue to pay royalties may very well invoke leave and licence and thus excuse the trespass on the part of the lessee.

In hindsight, the lessor erred in Williston in making ill-advised and conciliatory statements and concessions that enabled the Court to hold as it did. Where the lessor does nothing except issue a court challenge to the validity of the lease, it would seem unlikely that the doctrine of leave and licence could be successfully invoked by the lessec. If it were otherwise, the lessee under a defunct lease could blithely continue to occupy the land and reap the benefits as if the lease had never come to an end.

On the matter of damages, however, the decision at both trial and appeal levels leads to a result that, it is submitted, is flawed and could lead to an untoward result. Some comfort may be derived from the fact that decisions of a Court of Appeal are not binding on the courts of other provinces. ${ }^{29}$ 


\section{H. OWNERSHIP OF THE WELL}

The lease having terminated, the inevitable question arises: who owns the wellbore, downhole, and surface equipment?

The trial judge declined to deal with this question because he was not apprised of all the facts. Both partics requested the Court of Appeal to make a decision on the point, and agreed there was sufficient evidence before the Court to enable it to decide the issue.

In the normal course, the matter of who owns the well and, equally important, who is responsible for it, arranges itself satisfactorily. Production ceases, the lease comes to an end, and the lessee abandons the well and removes its equipment. For years, the oil and gas lease forms contained a provision virtually identical to $\mathrm{cl} .17$ in the Williston lease:

17. REMOVAL OF EQUIPMENT: - The Lessee shall at all times during the currency of this Lease and for a period of Six (6) months from the termination thereof, have the right to remove all or any of his machinery, equipment, structures, pipe lines, casing and muterials from the said lands. ${ }^{30}$

This was true until the CAPL99 form was released. This edition of the widely used form does not contain a clause granting the lessee the right to remove its materials from the lands. The reason for this omission is that the point is covered in the CAPL form of surface lease. ${ }^{31}$

The plaintiff in Williston argued (with some force, it seems to me) that the defendant could not rely on cl. 17 since the lease had terminated more than six months previously. The Court found this contention to be too simplistic in that it ignored the standard practice in the industry, and the fact that the defendants were on the land with the lessors' consent and that they took advantage of the equipment to have the leased substances produced and generate royalties.

In the Court's view, the standard practice of the industry confirms that the equipment belongs to the operator. This practice is further confirmed by the surface lease and also by the practice of the parties themselves. The Court went on to find that the lessee's ownership of the equipment was also consistent with the case law, quoting the 1912 case Maple City Oil \& Gas Co. v. Charlton, ${ }^{32}$ which followed McIntosh v. Leckie. ${ }^{33}$ In Maple City, the lessee, under an earlier lease that was found to be valid, could only take advantage of a well drilled by an operator under a subsequent invalid top lease by compensating the operator. In Willision, the Court of Appeal also referred to Weyburn, ${ }^{34}$ where the lessee was entitled to recover its costs from production.

Williston 2004 (C.A.), supra note 2 at para. 131. Sipra note 15.

(1912), 7 D.L.R. 345 (Ont. H.C.) [Maple C'ily].

(1906), 13 O.L.R. 54 (H.C.).

Supra note 19. 
In the course of its examination of the ownership question, the Court of Appeal made a footnote reference to Republic Resources $L \mathrm{l} d$. v. Ballem, ${ }^{35}$ but did not discuss it. While its fact pattern makes it clearly distinguishable from Williston, the Republic case merits consideration because it was the "purest" case involving restitution. In Republic, a gas well was drilled over the end of the primary term under a lease that contained the same language as had been found not to extend the lease in Kininmomil. ${ }^{36}$ The status of the lease was challenged before it was placed on production. The plaintiff lessec claimed to recover its cost of drilling the well undor the principle of restitution on the grounds of unjust enrichment. In support of its claim, the plaintiff relied on the ever popular Weyburn, and its ruling that a lessor of mineral rights may be required in equity to compensate a lessee lor expenditures made in mistakenly drilling a well under an expired oil and gas lease.

In his decision, after noting that neither the Saskatchewan Court of Appeal nor the Supreme Court discussed the principles on which they ordered restitutionary relief, Holmes J. pointed out the significant differences between Weyburn and Republic: in the former, the lessors, subsequent to the termination date, had knowledge ol the lessee's drilling activity. had aceepted royalty payments and other monetary benefits, and had requested the lessees to drill an offset well, which request had been complied with. None of these factors were present in the Republic situation.

Will industry practice prevail in a situation where the lessor has received no royalty nor other financial benefit from the well and has done nothing to suggest he or she is willing to let the operator remain in possession?

Ownership of the well can be of great value to the mineral owner where there is profitable and sustainable production; it can also be a two-edged sword, especially in the later stages of a well's productive life. The owner of a well at some point in time will be faced with abandonment and reclamation costs. ${ }^{37}$

(1982), 33 A.R. 385 (Q.B.) [Republic|. Professor Percy discussed this case and suggested that it could hamper the luttire application of restitution in mineral lealse cases (supro note 17). If, however, the concept of damages as enunciated in Willisten prevails in luture cases. reslitution will have been left far behind.

16 Supra note 13.

37 When it comes to Crown lands, there is no doubt about which party owns the well. See Mines and Minerals Act, R.S.A. 2000, c. M-17, s. 32, which provides that when an agreement expires, or is surrendered or cancelled, the ownership of any well in the location rests in the Crown in right of Alberta. 